\title{
Efficacy, safety and tolerability of using abatacept for the treatment of rheumatoid arthritis
}

\author{
Rafael Venson, Astrid Wiens, Cassyano Januário Correr, Roberto Pontarolo*
}

Pharmacy Department, Federal University of Paraná

\begin{abstract}
The objective is to provide an update on the clinical efficacy, safety and tolerability of the use of abatacept for treating rheumatoid arthritis. A systematic review (up to June 2011) followed by meta-analyses was performed. Randomized controlled clinical trials comparing abatacept at a dose of $10 \mathrm{mg} / \mathrm{kg}$ with a placebo, both with concomitant methotrexate, were used. Only high- or moderate-quality studies were included. The efficacy was evaluated based on changes in the ACR, DAS and HAQ; safety was assessed based on serious adverse events, serious infections, malignancies and deaths; tolerability was evaluated based on the withdrawals due to adverse events, serious adverse events and lack of efficacy. All these parameters were evaluated within one year of treatment. Nine studies met the inclusion criteria, comprising 4,219 patients. For all of the efficacy parameters, the abatacept group had better results than the placebo group, except in the case of HAQ improvement $>0.3$, which presented no statistically significant difference. None of the safety parameters presented a significant difference between the groups. The tolerability parameters were also similar between groups, with the exception of withdrawals due to lack of efficacy. For this criterion, the abatacept group presented favorably compared to the control group. Abatacept showed a higher efficacy compared to placebo without significant differences between the abatacept and control group in terms of safety.
\end{abstract}

Uniterms: Abatacept/efficacy. Rheumatoid arthritis/treatment. Meta-analyses.

O objetivo foi fornecer dados atualizados sobre eficácia clínica, segurança e tolerabilidade do uso de abatacepte para o tratamento da artrite reumatoide. Realizaram-se uma revisão sistemática (com dados até junho/2011) e metanálises. Somente estudos clínicos controlados randomizados comparando o abatacepte $(10 \mathrm{mg} / \mathrm{kg})$ com placebo, ambos com uso concomitante de metotrexato, foram incluídos; todos possuíam qualidade alta ou moderada. A eficácia foi avaliada baseando-se em mudanças no ACR, DAS e HAQ; a segurança foi avaliada pelos eventos adversos e infecções graves, malignidades e mortes e a tolerabilidade pelo abandono do tratamento devido a eventos adversos (graves ou não) e falta de eficácia. Todos esses parâmetros foram avaliados ao final de um ano de tratamento. Nove estudos se adequaram aos critérios de inclusão, envolvendo 4219 pacientes. Em todos os parâmetros avaliados, o grupo tratado com abatacepte obteve melhores resultados, exceto para a melhora $(>0,3)$ no HAQ (sem diferença estatisticamente significativa). Nenhum critério de segurança ou tolerabilidade apresentou diferença significativa entre os grupos, com exceção dos abandonos devido à falta de eficácia (grupo abatacepte apresentou resultados favoráveis em relação ao controle). O abatacepte possui maior eficácia quando comparado com o placebo, sem diferença significativa entre os grupos em termos de segurança.

Unitermos: Abatacepte/eficácia. Artrite reumatóide. Metanálise.

\section{INTRODUCTION}

Rheumatoid arthritis (RA) is a chronic autoimmune disease with a worldwide prevalence of approximately

\footnotetext{
*Correspondence: R. Pontarolo. Departamento de Farmácia, Universidade Federal do Paraná. Av. Prefeito Lothário Meissner, 632 - Jardim Botânico, 80210-170 - Curitiba - PR - Brasil. E-mail: pontarolo@ufpr.br
}

$1 \%$. The disease leads to joint inflammation and destruction and generates a decrease in the health-related quality of life, functional limitations and work disability, mainly due to pain and fatigue (Bagust et al., 2009; Singh et al., 2009; Cortejoso-Fernandez et al., 2012).

Cytokines, interleukins- $1 \beta$ and 6 (IL-1 $\beta$ and 6 ) and tumor necrosis factor (TNF) are known to play important roles in joint destruction in RA. The activation of T and $\mathrm{B}$ 
cells leads to a cascade of events, including the release of cytokines that are responsible for inflammation and joint destruction. Abatacept (ABT) modulates the stimulation of T cells, which subsequently control the function of B cells, macrophages and osteoclasts and the release of cytokines, matrix metalloproteinases and antibodies (Bruce, 2009; Falgarone et al., 2009). ABT is a fusion protein made up of the Fe portion of human immunoglobulin and cytotoxic T-lymphocyte associated antigen 4 . ABT blocks the cascade of activation of T cells (Smolen et al., 2007; Bruce, 2009; Mola et al., 2012).

ABT was shown to be safe and efficient for patients with an inadequate response to TNF antagonists and methotrexate (MTX) in some randomized controlled clinical trials (RCT). Treatment with ABT resulted in decreases in arthritis, pain, disability, fatigue and radiological joint damage, and the efficacy was maintained over time (Genovese et al., 2005; Kremer et al., 2005; Kremer et al., 2006; Genant et al., 2008; Schiff et al., 2008; Falgarone et al., 2009; Rubbert-Roth; Finckh, 2009; Russell et al., 2009; Russell et al., 2009; Mola et al., 2012).

Although RTC have shown the effectiveness of ABT in treating the signs and symptoms of $\mathrm{AR}$, indiscriminate use must be avoided and continued evaluations must be conducted due to the lack of information about the longterm safety (Cortejoso-Fernández et al., 2012). According to a review by Cochrane, ABT presents a better safety profile than most other biologics (Malaviya, Östör, 2012). This study provides a systematic review and meta-analyses to evaluate the efficacy, safety and tolerability of ABT pharmacotherapy for RA interventions based on updated evidence, including systematic reviews and meta-analyses.

\section{METHODS}

A systematic review and meta-analyses were performed of RCT that compared the use of ABT at a dose of 10 $\mathrm{mg} / \mathrm{kg}$ versus placebo, both with concomitant MTX. In the included studies, ABT was given endovenously at days 1,15 and 29 and every 4 weeks thereafter. Only studies involving adult patients with active RA (as defined by the American College of Rheumatology - ACR - criteria) and with moderate to high quality were included (according to Jadad's Scale) (Jadad et al., 1996). Other inclusion criteria were as follows: studies that reported clinical outcomes and were available as full-text publications. Interventional studies were excluded if they were not randomized or double-blind.

Two independent reviewers performed the systematic review and applied Jadad's Scale (Jadad et al., 1996) for quality evaluation of the studies. The two reviewers extracted the data from the articles in pre-defined tables.
In the case of a difference between the data extracted by the reviewers, the discordant data were discussed and consensual values were adopted.

The electronic databases used in the systematic review were as follows: Medline, Embase, Chocrane Library, Scielo, Lilacs and International Pharmaceutical Abstracts. The search was performed for relevant studies up to June 2011. Language and date of study publication were not exclusion criteria. As descriptors, the following expressions were used: rheumatoid arthritis AND abatacept. No search filters were used for the type of study restriction, except for in Medline (in which we only looked for clinical trials, meta-analyses, RCT, and clinical trials) and IPA (in which we only searched for original articles).

The clinical outcomes adopted for the evaluation of treatment were the following: the response of RA to treatment with ABT according to the ACR criteria (ACR 20, 50 and 70); a Disease Activity Score in 28 joints indicating the remission of the pathology (DAS28 $\leq 2.6)$ and a low disease activity (DAS28 $\leq 3.2$ ); and HAQ variation and improvement $(\triangle \mathrm{HAQ} \geq 0.3)$. Additionally, the safety outcomes considered were as follows: serious adverse events (SAE), serious infections (SI), malignancies and deaths. For the tolerability evaluation, withdrawals due to adverse events, SAE or lack of efficacy were measured. All parameters were evaluated after one year of treatment, according to the available data in the included studies.

For statistical analyses, the software Review Manager 5.0, from Cochrane Collaboration, was used. Dichotomous variables were evaluated using the risk ratio with the inverse variance model, with a confidence interval of $95 \%$ (random effect model). HAQ variation was the only continuous variable, and it was evaluated by the mean difference and inverse variance model, with the same confidence interval. The random effect model was chosen due to the high heterogeneity in the data that could not be explained.

Statistical heterogeneity among the results was assessed using $\mathrm{I}^{2}$, a common metric method for measuring the magnitude of this variable. The interpretation of $\mathrm{I}^{2}$ is relatively simple: its value varies from $0 \%$ to $100 \%$, and in situations where $\mathrm{I}^{2}<25 \%$, the statistical heterogeneity is considered low; it is considered moderate and high for values between $25 \%$ and $50 \%$ and for values above $50 \%$, respectively (Hakkinen et al., 2006; Huedo-Medina et al., 2006).

A sensitivity analysis was also performed in this study. The method adopted for evaluating the robustness of the study was as follows: the data were reviewed with exclusion of data of studies or groups of studies. The data were also reviewed using different statistical methods. 


\section{RESULTS}

In the systematic review, 42 potentially relevant articles were identified, of which 29 were excluded on the basis of the title or abstract. The remaining 13 articles were evaluated by two independent reviewers, and 4 studies were excluded upon reading the full text. The remaining 9 articles were included in the meta-analyses based on their quality and their accordance with the inclusion criteria. Figure 1 is a scheme of the systematic review, and Table I shows the main characteristics of the excluded studies and the reasons for their exclusion.

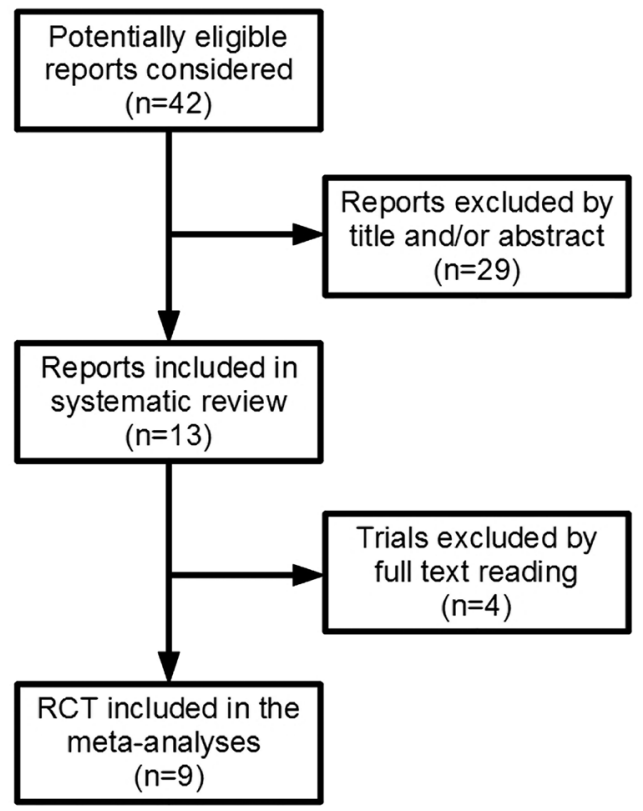

FIGURE 1 - Results of the systematic review. RCT - Randomized controlled trial.

\section{Description of the included studies}

Twelve studies met the inclusion criteria and were included in the meta-analyses. All of the included studies were sponsored by Bristol-Myers Squibb. A chronological summary of the baseline characteristics of the patients involved in the included studies is shown in Table II.

The mean age of the patients across all trials ranged from 49.1 to 54.6 years. The gender distribution was also similar across trials (all trials had a 3:1 ratio of females to males). Both the mean age and gender distribution values are consistent with the epidemiology of RA $[1,2]$. The data for the mean number of swollen and tender joints were also similar across the studies; however, the mean disease duration was heterogeneous across the studies (ranged from 3.4 to 12.9 years).
TABLE I - Characteristics of the excluded studies

REFERENCE REASON FOR EXCLUSION

Alten, 2006

Chung, 2006

Genant, 2008

Genovese, 2008

Kremer, 2008

Maxwell, 2009

Ostor, 2008

Russell, 2009

Not a randomized controlled clinical trial

Schiff, 2009

Singh, 2009

Singh, 2009

Vera-Llonch, 2008

Venkateshan, 2009

Westhovens, 2009

\begin{tabular}{ll}
\hline Dougados, 2009 & Without a control group \\
\hline Hasset, 2008 & $\begin{array}{l}\text { Analyzed data from another study } \\
\text { (Genovese } \text { et al., 2005) }\end{array}$ \\
\hline $\begin{array}{l}\text { Li, 2008 } \\
\text { Moreland, 2002 }\end{array}$ & $\begin{array}{l}\text { Involved an intervention that was not } \\
\text { relevant for this meta-analyses }\end{array}$ \\
\hline Ma, 2009 & Pharmacokinetic study \\
\hline
\end{tabular}

Cole, 2008

Emery, 2006

Marti, 2009

Martin, 2007

Russel, 2007

Compared outcomes that were not of

Weisman, 2006

interest for the meta-analyses

Wells, 2008

Westhovens, 2006

\begin{tabular}{ll}
\hline Ruperto, 2008 & $\begin{array}{l}\text { Abatacept was prescribed for juvenile } \\
\text { rheumatoid arthritis }\end{array}$ \\
\hline Salliot 2009 & Adverse events meta-analysis
\end{tabular}

Salliot, $2009 \quad$ Adverse events meta-analysis

\section{Meta-analyses results for efficacy}

For evaluation of the efficacy of ABT, the following data were extracted from the studies: the proportion of patients who achieved ACR20, ACR50, ACR70, DAS28 $\leq 3.2$ and DAS28 $\leq 2.6$; the mean HAQ variation from baseline to the end of the follow-up; and the proportion of patients who showed an improvement of 0.3 or more in the HAQ scale. All the parameters were measured after one year of continuous treatment.

Considering the ACR outcomes, four studies provided data of the outcomes within one year of treatment (Kremer et al., 2005; Kremer et al., 2006; Schiff et al., 2008; Westhovens et al., 2009a). In two other studies, the interventions included concomitant anti-TNF agent (Genovese et al., 2005; Weinblatt et al., 2007). The articles 
used in the meta-analyses involved the following intervention: ABT 10mg/kg+MTX versus placebo+MTX.

The Risk Ratios (RR) comparing ABT versus the control groups were as follows: 1.60 [1.28, 2.01] for ACR20, 1.98 [1.35, 2.91] for ACR50 and 2.47 [1.51, 4.03] for ACR70 (Figure 2). In total, $71 \%$ of the patients achieved ACR2 0 after one year of treatment with ABT compared to $43 \%$ of the control group. For ACR50 and ACR 70 , the values were $49 \%$ and $37 \%$ for the ABT group and $28 \%$ and $16 \%$ for the control group, respectively.

High statistical heterogeneities among the studies $\left(\mathrm{I}^{2}>50 \%\right.$ ) were observed for the three outcomes (ACR20, 50 and 70). No clinical or methodological differences among the studies were observed to be able to cause these heterogeneities.

The proportions of patients with low disease activity and who experienced remission were also evaluated in our meta-analyses using DAS28. The RR values comparing the ABT and control groups were $3.09[1.68,5.68]$ and 3.88 $[1.48,10.16]$ for the percentages of patients who achieved DAS $28 \leq 3.2$ (low disease activity) and DAS $28 \leq 2.6$ (disease remission), respectively, within one year of treatment. In total, $44 \%$ of patients achieved values of DAS $28 \leq 3.2$ in the ABT group; in the control group, this value was $14 \%$. A total of $31 \%$ of the patients in the ABT group presented remission of the disease according to the DAS28 criteria; for the control group, this value was 13\% (Figure 3).

The statistical heterogeneity was high for both of the DAS28 outcomes. No clinical or methodological differences in the studies could account for this heterogeneity.

The meta-analysis of the variation of the HAQ from baseline to the end of follow-up involved only two stud-

TABLE II - Patients' baseline characteristics in the included studies

\begin{tabular}{|c|c|c|c|c|c|c|c|}
\hline $\begin{array}{l}\text { Study (Jadad Score) } \\
\text { Intervention }\end{array}$ & $\begin{array}{c}\text { Number of } \\
\text { patients }\end{array}$ & $\begin{array}{l}\text { Mean age } \\
\text { (years) }\end{array}$ & $\begin{array}{c}\text { Mean disease } \\
\text { duration } \\
\text { (years) }\end{array}$ & $\begin{array}{c}\text { Mean number } \\
\text { of swollen } \\
\text { joints } \\
\end{array}$ & $\begin{array}{c}\text { Mean number } \\
\text { of tender } \\
\text { joints } \\
\end{array}$ & $\begin{array}{c}\% \text { of } \\
\text { patients on } \\
\text { DMARD } \\
\end{array}$ & $\begin{array}{l}\text { Mean } \\
\text { HAQ } \\
\text { score } \\
\end{array}$ \\
\hline $\begin{array}{l}\text { Moreland, } 2002 \text { (4) } \\
\text { ABT 10mg/kg + MTX } \\
\text { Placebo + MTX } \\
\end{array}$ & 64 & 51.5 & 3.4 & 23.3 & 29.5 & N.A. & N.A. \\
\hline $\begin{array}{l}\text { Kremer, } 2003(4) \\
\text { ABT 10mg/kg + MTX } \\
\text { Placebo + MTX } \\
\end{array}$ & 234 & 54.6 & 9.3 & 21.1 & 28.7 & N.A. & 1.0 \\
\hline $\begin{array}{l}\text { Genovese, } 2005 *(5) \\
\text { ABT 10mg/kg + MTX } \\
\text { Placebo + MTX } \\
\end{array}$ & 391 & 53.2 & 11.9 & 22.2 & 31.7 & N.A. & 1.8 \\
\hline $\begin{array}{l}\text { Kremer, } 2005(4) \\
\text { ABT 10mg/kg + MTX } \\
\text { Placebo + MTX } \\
\end{array}$ & 234 & 54.6 & 9.3 & 21.1 & 28.7 & N.A. & N.A. \\
\hline $\begin{array}{l}\text { Kremer, } 2006(4) \\
\text { ABT 10mg/kg + MTX } \\
\text { Placebo + MTX } \\
\end{array}$ & 652 & 51.1 & 8.6 & 21.6 & 31.4 & 11.0 & 1.7 \\
\hline $\begin{array}{l}\text { Weinblatt, } 2006 \text { (5) } \\
\text { ABT 10mg/kg + DMARD } \\
\text { Placebo + DMARD } \\
\end{array}$ & 1274 & 52.1 & 9.5 & 19.8 & 28.9 & 89.8 & 1.5 \\
\hline $\begin{array}{l}\text { Weinblatt, } 2007 \text { (4) } \\
\text { ABT 10mg/kg + ETA } \\
\text { Placebo + ETA } \\
\end{array}$ & 121 & 51.1 & 12.9 & 19.7 & 28.8 & N.A. & N.A. \\
\hline $\begin{array}{l}\text { Schiff, } 2008(5) \\
\text { ABT 10mg/kg + MTX } \\
\text { Placebo + MTX } \\
\end{array}$ & 266 & 49.1 & 8.1 & 20.8 & 31.1 & N.A. & 1.8 \\
\hline $\begin{array}{l}\text { Westhovens, } 2009 \text { (4) } \\
\text { ABT 10mg/kg + MTX } \\
\text { Placebo + MTX }\end{array}$ & 509 & 49.9 & 6.4 & 22.4 & 31.1 & 3.3 & 1.7 \\
\hline
\end{tabular}




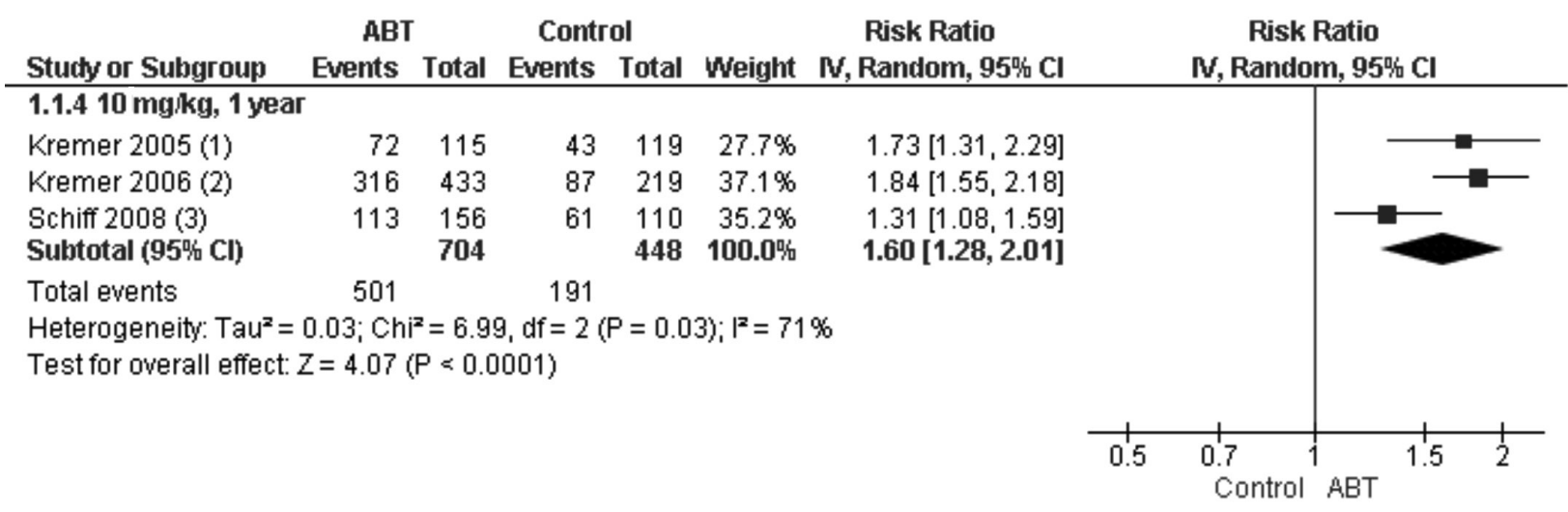

(1) $A B T+M T X$ vs. Placebo+MTX

(2) $A B T+M T X$ vs. Placebo+MTX

(3) $A B T+M T X$ vs. Placebo+MTX

\begin{tabular}{|c|c|c|c|c|c|c|c|}
\hline \multirow{2}{*}{$\frac{\text { Study or Subgroup }}{1.2 .410 \mathrm{mg} / \mathrm{kg}, 1 \text { year }}$} & \multicolumn{2}{|l|}{ ABT } & \multicolumn{2}{|c|}{ Control } & Weight & $\begin{array}{c}\text { Risk Ratio } \\
\text { N, Random, 95\% Cl }\end{array}$ & $\begin{array}{c}\text { Risk Ratio } \\
\text { N, Random, 95\% Cl }\end{array}$ \\
\hline & & & & & & & \\
\hline Kremer 2005 (1) & 48 & 115 & 24 & 119 & $22.5 \%$ & $2.07[1.36,3.14]$ & \\
\hline Kremer $2006(2)$ & 209 & 433 & 40 & 219 & $26.0 \%$ & $2.64[1.96,3.56]$ & \\
\hline Schiff $2008(3)$ & 71 & 156 & 22 & 110 & $22.7 \%$ & $2.28[1.51,3.43]$ & \\
\hline $\begin{array}{l}\text { Westhovens } 2009 \text { (4) } \\
\text { Subtotal (95\% Cl) }\end{array}$ & 147 & $\begin{array}{l}256 \\
960\end{array}$ & 109 & $\begin{array}{l}253 \\
701\end{array}$ & $\begin{array}{r}28.9 \% \\
100.0 \%\end{array}$ & $\begin{array}{r}1.33[1.12,1.59] \\
\mathbf{1 . 9 8}[1.35,2.91]\end{array}$ & $\rightarrow-$ \\
\hline $\begin{array}{l}\text { Total events } \\
\text { Heterogeneity: } \operatorname{Tau}^{2}=0 \\
\text { Test for overall effect: } Z\end{array}$ & $\begin{array}{c}475 \\
12 ; \mathrm{Chi}^{2}= \\
=3.52(\mathrm{P}=\end{array}$ & $\begin{array}{l}=18.57 \\
=0.000\end{array}$ & $\begin{array}{l}195 \\
\mathrm{df}=3(\mathrm{P}\end{array}$ & $=0.00$ & $003 ;\left.\right|^{2}=8$ & $4 \%$ & \\
\hline
\end{tabular}

(1) $A B T+M T X$ vs. Placebo+MTX

(2) $A B T+M T X$ vs. Placebo+MTX

(3) $A B T+M T X$ vs. Placebo+MTX

(4) $A B T+M T X$ vs. Placebo+MTX

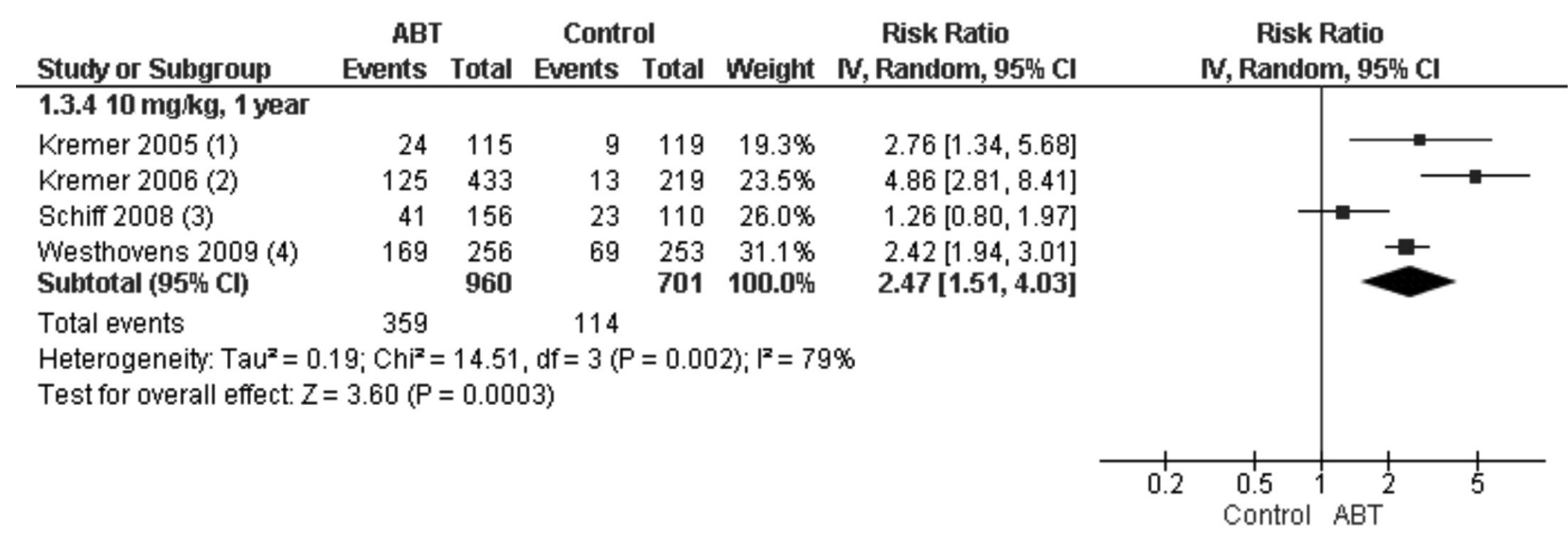
(1) $A B T+M T X v s$. Placebo+MTX
(2) $A B T+M T X$ vs. Placebo+MTX
(3) $A B T+M T X$ vs. Placebo+MTX
(4) $A B T+M T X$ vs. Placebo+MTX

FIGURE 2 - Meta-analysis of ACR20 (top), ACR50 (middle) and ACR70 (bottom). ABT - abatacept; MTX - methotrexate. IV inverse variance; $\mathrm{CI}$ - confidence interval. 


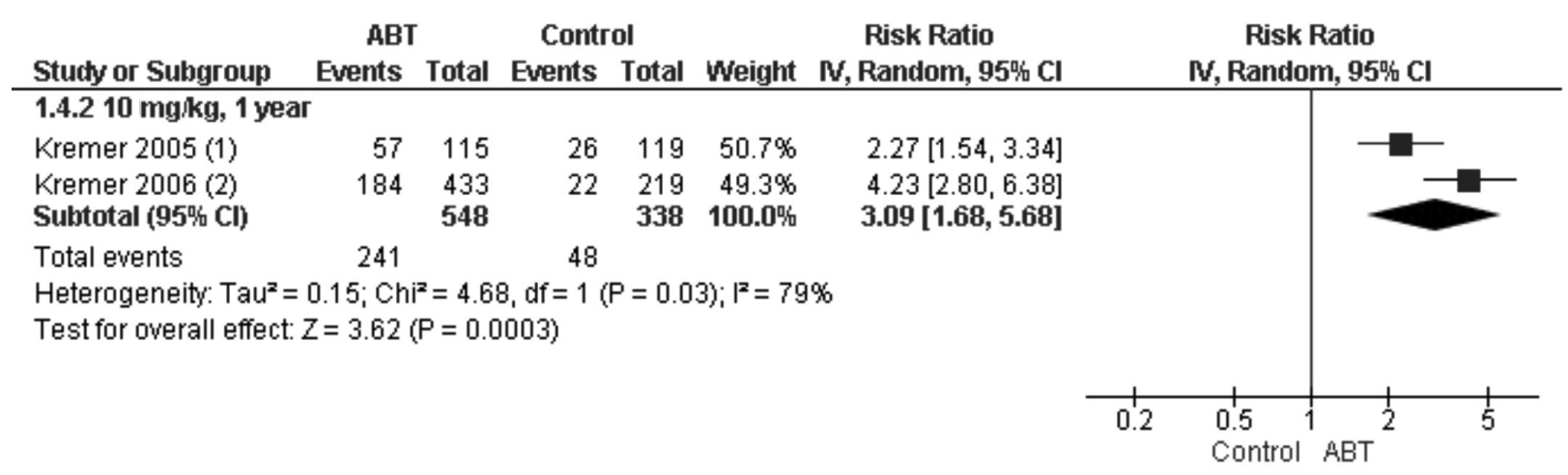

(1) $A B T+M T X$ vs. Placebo+MTX

(2) $A B T+M T X$ vs. Placebo+MTX

\begin{tabular}{|c|c|c|c|c|c|c|c|c|c|c|}
\hline \multirow{2}{*}{$\frac{\text { Stucty or Subgroup }}{1.5 .210 \mathrm{mg} / \mathrm{kg}, 1 \text { year }}$} & ABT & Total & Control & Total & Weight & $\begin{array}{c}\text { Risk Ratio } \\
\text { N, Random, 95\% } \mathrm{Cl}\end{array}$ & \multicolumn{4}{|c|}{ 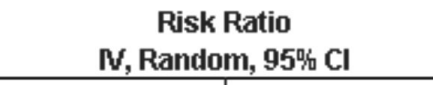 } \\
\hline & & & & & & & & & & \\
\hline Kremer 2005 (1) & 40 & 115 & 12 & 119 & $34.1 \%$ & $3.45[1.91,6.23]$ & & & & \\
\hline Kremer 2006 (2) & 103 & 433 & 4 & 219 & $27.8 \%$ & $13.02[4.86,34.89]$ & & & & \\
\hline $\begin{array}{l}\text { Westhovens } 2009 \text { (3) } \\
\text { Subtotal (95\% Cl) }\end{array}$ & 106 & $\begin{array}{l}256 \\
804\end{array}$ & 59 & $\begin{array}{l}253 \\
591\end{array}$ & $\begin{array}{r}38.1 \% \\
100.0 \%\end{array}$ & $\begin{array}{r}1.78[1.36,2.32] \\
\mathbf{3 . 8 8}[\mathbf{1 . 4 8}, \mathbf{1 0 . 1 6}]\end{array}$ & & & & \\
\hline \multirow{3}{*}{$\begin{array}{l}\text { Total events } \\
\text { Heterogeneity: } \text { Tau }^{2}=0 \\
\text { Test for overall effect: } Z\end{array}$} & & & 75 & & & & & & & \\
\hline & $\begin{array}{l}62 ; \mathrm{Chi}^{2} \\
=2.75(\mathrm{P}\end{array}$ & $\begin{array}{l}=17.20 \\
=0.006\end{array}$ & df $=2(P$ & $=0.00$ & $02) ;\left.\right|^{2}=$ & $38 \%$ & & & & \\
\hline & & & & & & & 0.05 & ${ }^{0.2}{ }^{1}$ & ABT ${ }^{5}$ & 20 \\
\hline
\end{tabular}
(1) $A B T+M T X v s$. Placebo+MTX
(2) $A B T+M T X$ us. Placebo+MTX
(3) $A B T+M T X$ vs. Placebo+MTX

FIGURE 3 - Meta-analysis of low disease activity (DAS $\leq 3.2$ ) and disease remission (DAS $\leq 2.6)$ - top and bottom, respectively. ABT - abatacept; MTX - methotrexate. IV - inverse variance; CI - confidence interval.

ies (Kremer et al., 2006; Westhovens et al., 2009a), both of which had ABT + MTX versus placebo+MTX as the intervention. The values included in the meta-analysis resulted in a mean difference of $0.19[0.20,0.19]$, favoring the ABT group. A high heterogeneity was also observed in this parameter, which could not be explained by the methodologies of the included studies (Figure 4).

For HAQ improvement $\geq 0.3$, two studies were included in the meta-analysis (Kremer et al., 2006; Westhovens et al., 2009a). The result was an RR value of $1.36[0.98,1.90]$, favoring the ABT group; however, this difference was not statistically significant. High heterogeneity was observed (Figure 4).

\section{Meta-analyses results for safety}

Table III summarizes the results concerning safety. Three studies provided data related to the SAE and SI for one year of treatment (Kremer et al., 2006; Jonsson; Kobelt; Smolen, 2008; Westhovens et al., 2009a). Data on death were available in four studies (Kremer et al., 2005; Kremer et al., 2006; Weinblatt et al., 2006; Westhovens et al., 2009a). Data on malignancies were extracted from four studies (Kremer et al., 2005; Kremer et al., 2006; Weinblatt et al., 2006; Westhovens et al., 2009a).

The RR values were not statistically significant for any of these items ( $p$ values of $0.19,0.58,0.82$ and 0.98 for SAE, SI, malignancies and deaths, respectively).

Only the SAE data had values of $\mathrm{I}^{2}$ higher than $25 \%\left(\mathrm{I}^{2}=39 \%\right)$, corresponding moderate heterogeneity. The study responsible for this heterogeneity was that of Weinblatt et al. (2006); the only difference between this study and the others was the possibility that the patients used other DMARD besides MTX.

\section{Meta-analyses results for tolerability}

The results concerning withdrawals due to $\mathrm{AE}, \mathrm{SAE}$ and a lack of efficacy for ABT at a dose of $10 \mathrm{mg} / \mathrm{kg}$ within one year of treatment are summarized in Figure 5. 


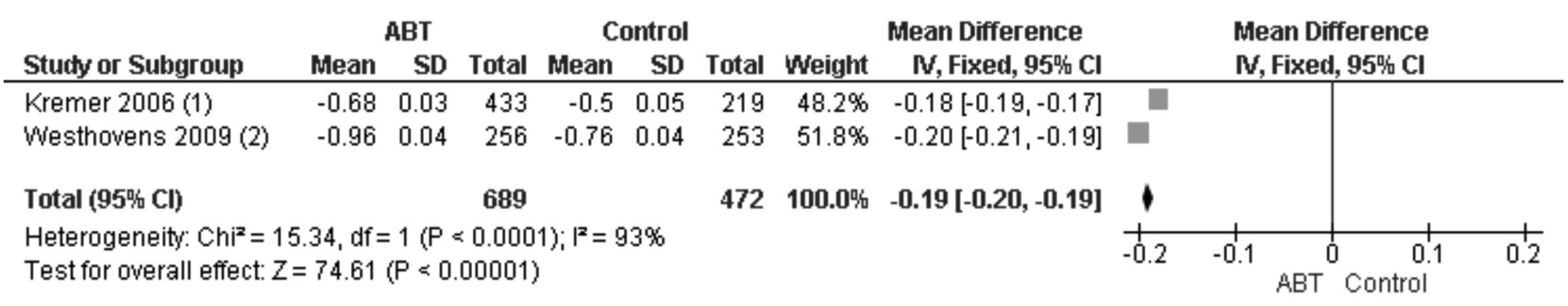

(1) $A B T+M T X v s$. Placebo+MTX

(2) $A B T+M T X$ vs. Placebo+MTX

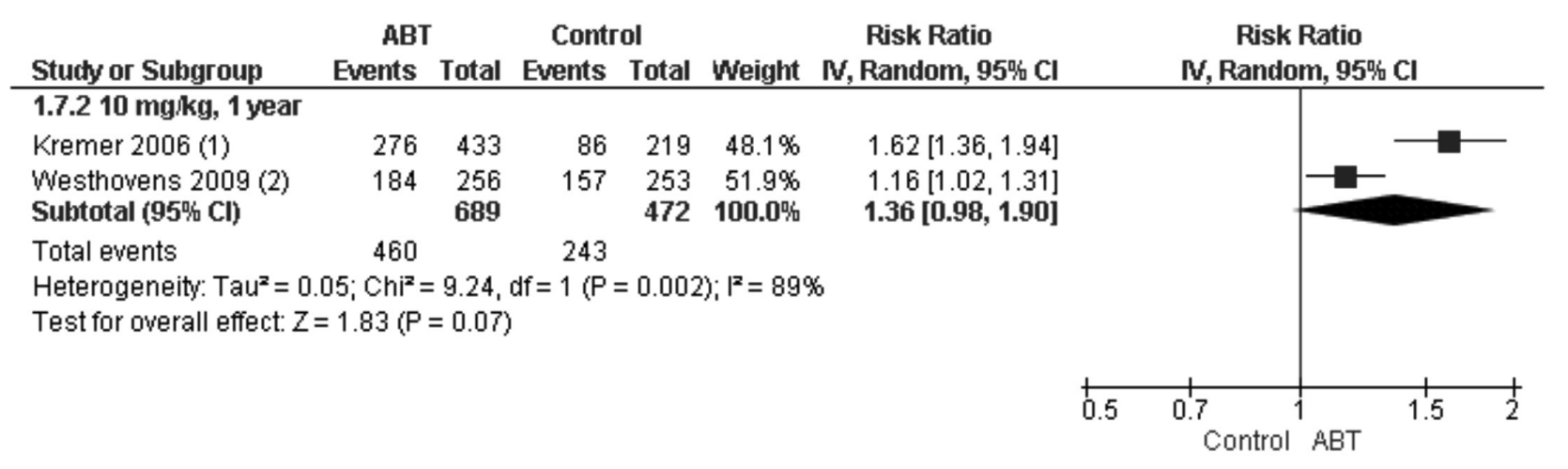

(1) $A B T+M T X$ vs. Placebo+MTX

(2) ABT+MTX vs. Placebo+MTX

FIGURE 4 - Meta-analyses of HAQ variation (top) and HAQ improvement $\geq 0.3$ (bottom). ABT - abatacept; MTX - methotrexate. IV - inverse variance; $\mathrm{CI}$ - confidence interval; SD - standard deviation.

TABLE III - Safety results

\begin{tabular}{lcccc}
\hline Outcome & Studies & Participants & Statistical Method & Effect Estimate \\
\hline SAE & 3 & 2435 & Risk Ratio (IV, Random, 95\% CI) & $1.27[0.76,2.13]$ \\
SI & 3 & 2435 & Risk Ratio (IV, Random, 95\% CI) & $1.52[0.81,2.85]$ \\
Malignancies & 4 & 2669 & Risk Ratio (IV, Random, 95\% CI) & $0.93[0.55,1.57]$ \\
Deaths & 4 & 2669 & Risk Ratio (IV, Random, 95\% CI) & $0.56[0.21,1.47]$ \\
\hline
\end{tabular}

SAE: serious adverse events; SI: serious infections; IV: inverse variance; CI: confidence interval

There were no statistically significant differences between the intervention and control groups in any of the evaluated parameters, except in the meta-analysis of the proportion of patients who withdrew from treatment due to a lack of efficacy (RR of $0.29[0.12,0.71]$ ). This parameter exhibited high heterogeneity $\left(\mathrm{I}^{2}=64 \%\right)$, which could not be explained by methodological differences between the studies. The value of RR of the withdrawals due to AE within one year of treatment also exhibited high heterogeneity, although the RR value was not statistically significant.

\section{DISCUSSION}

DMARDs and anticytokines, such as adalimumab, etanercept or infliximab, are used worldwide to control the symptoms of RA, but in some patients, the results are not satisfactory (Bértolo et al., 2007; Russell, A. et al., 2009). Other biological agents have been developed to treat these refractory patients. Recent studies showed the effectiveness of these agents, including ABT and rituximab (RTX), for the treatment of RA. The evidence obtained from clinical trials is promising for the reduction of disease progression (Toussirot; Wendling, 2004; Smolen et al., 2007). The remission of the disease is more likely when $\mathrm{ABT}$ is used in the early stages of RA (Tang et al., 2008); in this study, only two trials (Moreland et al., 2002; Westhovens et al., 2009a) included patients who were within less than three years of disease onset.

In this study, the ABT-treated patients showed better efficacy and tolerability, compared to the control group. 


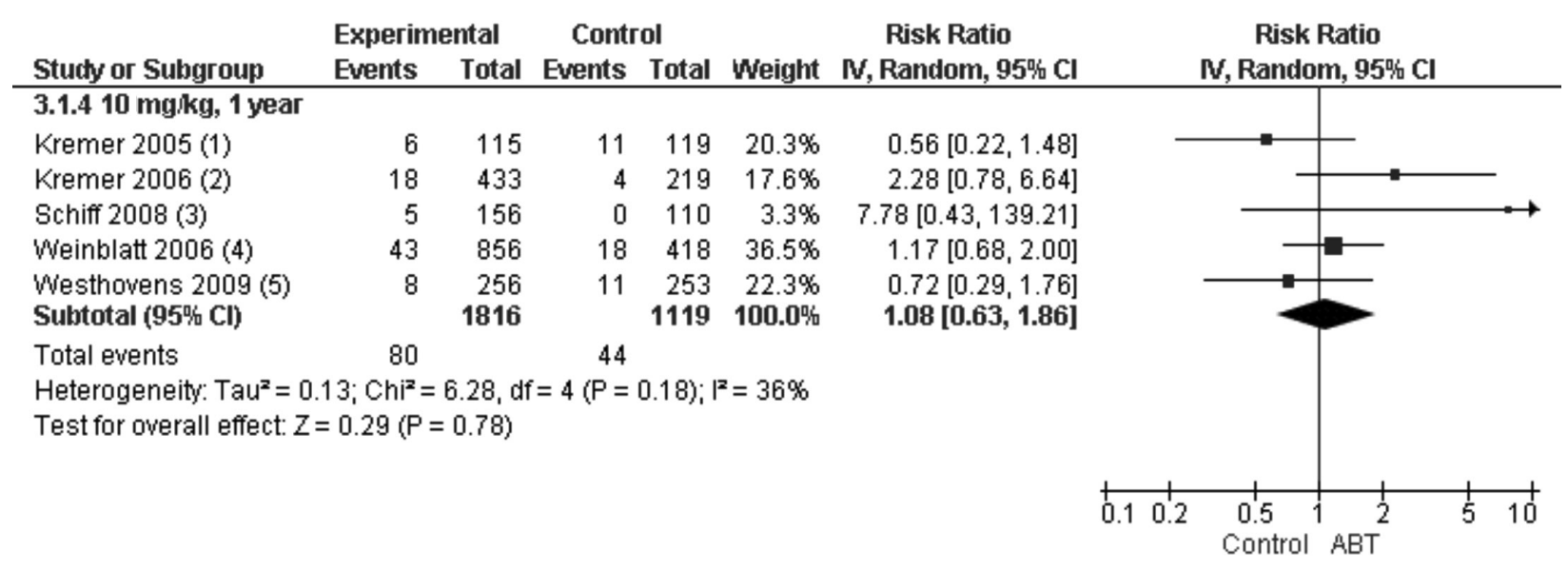

(1) $A B T+M T X$ vs. Placebo+MTX

(2) $A B T+M T X$ vs. Placebo+MTX

(3) $A B T+M T X$ vs. Placebo+MTX

(4) $A B T+D M A R D$ vs. Placebo+DMARD

(5) $A B T+M T X$ vs. Placebo+MTX

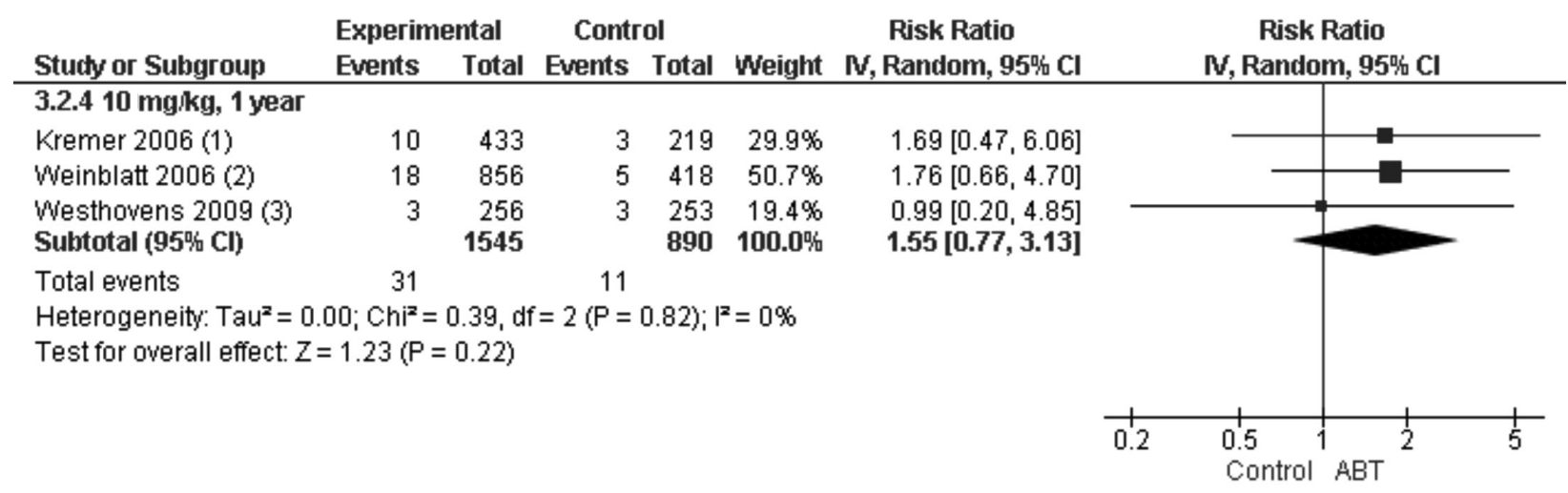

(1) $A B T+M T X$ vs. Placebo+MTX

(2) $A B T+D M A R D$ vs. Placebo+DMARD

(3) $A B T+M T X$ vs. Placebo+MTX

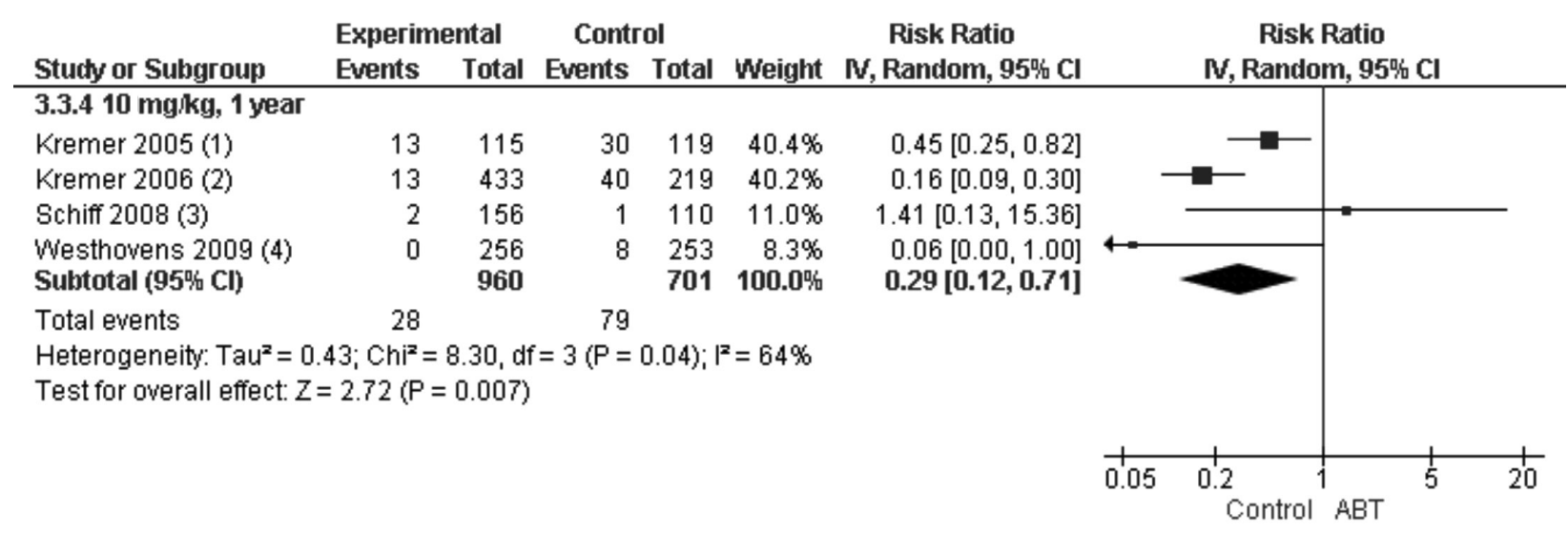
(1) $A B T+M T X v s$. Placebo+MTX
(2) $A B T+M T X$ vs. Placebo+MTX
(3) $A B T+M T X$ vs. Placebo+MTX
(4) $A B T+M T X$ vs. Placebo+MTX

FIGURE 5 - Meta-analysis of withdrawals due to AE, SAE and a lack of efficacy (top, middle and bottom, respectively). ABT abatacept; MTX - methotrexate. IV - inverse variance; CI - confidence interval. 
Better efficacy after one year of treatment was observed for all of the considered parameters (ACR20, ACR50, ACR70, DAS28 $\leq 3.2, \mathrm{DAS} 28 \leq 2.6$, mean HAQ variation, and the proportion of patients who had an improvement of 0.3 or more in the HAQ scale). The lower efficacy of the control group was also observed in the results of the meta-analyses of the withdrawals due lack of efficacy.

Our meta-analyses included the results of studies involving patients with early RA and patients with a long disease duration (with a mean duration of disease varying from 3.2 years to 12.2 years).

The safety data showed no differences between the groups with regard to SAE, serious infections, malignancy and deaths. The results of the analysis of withdrawals due to AE confirm this data, as there were no significant differences between the groups. Some of the common AE, SAE and serious infections cited in the studies were nausea, upper respiratory tract infection, headache, flu syndrome, rash and injection site reaction (Weinblatt et al., 2006; Westhovens et al., 2009b).

Other meta-analyses (Singh et al., 2009) have also shown benefits associated with the use of ABT instead of placebo $(\mathrm{OR}=2.98$ [1.79, 4.97]; RR = 1.03 (Zhang; Yu, 1998)), including six studies with a total of 1712 patients that considered ACR50 as the effectiveness outcome. The same study presented a value of OR equal to 1.24 [0.88, 1.76] $(\mathrm{RR}=1.01$ (Zhang; Yu, 1998)) for withdrawals due to AE; their meta-analysis included the same six studies but with a total of 1441 patients. Another meta-analysis presented similar results for the ACR50 $(\mathrm{OR}=3.28[2.44$, 4.41]; RR = 1.04 (Zhang; Yu, 1998)) but used the MantelHaenszel method instead of the inverse variance method (Salliot et al.).

Only RCT were included in this study for the evaluation of outcomes. However, long-term observational studies can provide a more realistic long-term estimation of the outcomes, especially the safety-related ones, reflecting the risks of ABT in the "real world". RCT have insufficient numbers of patients and follow-up times to detect rare SAE.

This study included some important clinical outcomes, such as the ACR and DAS28; however, other relevant outcomes could not be analyzed (such as radiographic progression) because they were less often included in the reviewed $\mathrm{RCT}$.

\section{CONCLUSION}

Our meta-analyses provided an updated comprehensive picture of the clinical efficacy, safety and tolerability of ABT, which presented a higher efficacy for all considered parameters (ACR20, ACR50, ACR70, DAS28 $\leq 3.2$,
DAS28 $\leq 2.6$, mean HAQ variation, and the proportion of patients who had an improvement of 0.3 or more in the HAQ scale) compared to placebo. However, there were no significant differences between the ABT and control groups in terms of safety and withdrawals due to $\mathrm{AE}$ and SAE. Furthermore, the ABT group presented fewer withdrawals due to lack of efficacy.

\section{ACKNOWLEDGMENTS}

The authors declare that they have no conflict of interest.

\section{FUNDING SOURCES}

Decit/SCTIE/MS, via Conselho Nacional de Desenvolvimento Científico e Tecnológico (CNPq) and supported by Fundação Araucaria.

\section{REFERENCES}

BAGUST, A.; BOLAND, A.; HOCKENHULL, J.; FLEEMAN, N.; GREENHALGH, J.; DUNDAR, Y.; PROUDLOVE, C.; KENNEDY, T.; MOOTS, R.; WILLIAMSON, P.; DICKSON, R. Rituximab for the treatment of rheumatoid arthritis. Health Technol. Assess., v.13, n.9, p.23-29, 2009.

BÉRTOLO, M.B.; BRENO, C.V.; SCHAINBERG, C.G.; NEUBARTH, F.; LIMA, F.A.C.D.; LAURINDO, I.M.; SILVEIRA, I.G.; PEREIRA, I.A.; LOURES, M.A.R.; AZEVEDO, M.N.D.; FREITAS, M.V.C.D.; NETO, M.D.S.P.; XAVIER, R.M.; GIORGI, R.D.N.; KOWALSKI, S.C.; ANTI, S.M.A. Atualização do consenso brasileiro no diagnóstico e tratamento da artrite reumatóide. Rev. Bras. Reumatol., v.47, n.3, p.151-159, 2007.

BRUCE, S.P. Recent Developments in the Treatment of Rheumatoid Arthritis. J. Pharm. Pract., v.22, n.1, p.65-74, 2009.

CORTEJOSO-FERNANDEZ, L.; ROMERO-JIMENEZ, M.R.; PERNIA-LOPEZ, M.S.; MONTORO-ALVAREZ, M.; SANJURJO-SAEZ, M. Effectiveness and safety of abatacept in moderate to severe rheumatoid arthritis. $J$. Pharm. Pharm. Sci., v.15, n.1, p.46-51, 2012.

CORTEJOSO-FERNÁNDEZ, L.; ROMERO-JIMÉNEZ, M.R.; MARÍA, S.P.-L.; MONTORO-ÁLVAREZ, M.; SANJURJO-SÁEZ, M. Effectiveness and Safety of Abatacept in Moderate to Severe Rheumatoid Arthritis. $J$. Pharm. Pharm. Sci., v.15, n.1, p.46-51, 2012. 
FALGARONE, G.; SEMERANO, L.; RULLE, S.; BOISSIER, M.C. Targeting lymphocyte activation to treat rheumatoid arthritis. Joint Bone Spine, v.76, n.4, p.327-332, 2009.

GENANT, H.K.; PETERFY, C.G.; WESTHOVENS, R.; BECKER, J.C.; ARANDA, R.; VRATSANOS, G.; TENG, J.; KREMER, J.M. Abatacept inhibits progression of structural damage in rheumatoid arthritis: results from the long-term extension of the AIM trial. Ann. Rheum. Dis., v.67, n.8, p.1084-1089, 2008.

GENOVESE, M.C.; BECKER, J.C.; SCHIFF, M.; LUGGEN, M.; SHERRER, Y.; KREMER, J.; BIRBARA, C.; BOX, J.; NATARAJAN, K.; NUAMAH, I.; LI, T.; ARANDA, R.; HAGERTY, D.T.; DOUGADOS, M. Abatacept for rheumatoid arthritis refractory to tumor necrosis factor alpha inhibition. N. Engl. J. Med., v.353, n.11, p.1114-1123, 2005.

HAKKINEN, A.; KAUTIAINEN, H.; HANNONEN, P.; YLINEN, J.; MAKINEN, H.; SOKKA, T. Muscle strength, pain, and disease activity explain individual subdimensions of the Health Assessment Questionnaire disability index, especially in women with rheumatoid arthritis. Ann. Rheum. Dis., v.65, n.1, p.30-34, 2006.

HUEDO-MEDINA, T.B.; SANCHEZ-MECA, J.; MARINMARTINEZ, F.; BOTELLA, J. Assessing heterogeneity in meta-analysis: Q statistic or I2 index? Psychology Methods, v.11, n.2, p.193-206, 2006.

JADAD, A.R.; MOORE, R.A.; CARROLL, D.; JENKINSON, C.; REYNOLDS, D.J.; GAVAGHAN, D.J.; MCQUAY, H.J. Assessing the quality of reports of randomized clinical trials: is blinding necessary? Control. Clin. Trials, v.17, n.1, p.1-12, 1996.

JONSSON, B.; KOBELT, G.; SMOLEN, J. The burden of rheumatoid arthritis and access to treatment: uptake of new therapies. Eur. J. Health Econ., v.8, supp1.2, p. S6186, 2008.

KREMER, J.M.; DOUGADOS, M.; EMERY, P.; DUREZ, P.; SIBILIA, J.; SHERGY, W.; STEINFELD, S.; TINDALL, E.; BECKER, J.C.; LI, T.; NUAMAH, I.F.; ARANDA, R.; MORELAND, L.W. Treatment of rheumatoid arthritis with the selective costimulation modulator abatacept: twelvemonth results of a phase iib, double-blind, randomized, placebo-controlled trial. Arthritis Rheum., v.52, n.8, p.22632271, 2005.
KREMER, J.M.; GENANT, H.K.; MORELAND, L.W.; RUSSELL, A.S.; EMERY, P.; ABUD-MENDOZA, C.; SZECHINSKI, J.; LI, T.; GE, Z.; BECKER, J.C.; WESTHOVENS, R. Effects of abatacept in patients with methotrexate-resistant active rheumatoid arthritis: a randomized trial. Ann. Intern. Med., v.144, n.12, p.865876, 2006.

MALAVIYA, A.P.; ÖSTÖR, A.J. Drug adherence to biologic DMARDS with a special emphasis on the benefits of subcutaneous abatacept. Patient Prefer. Adherence, v.6, p.589-596, 2012.

MOLA, E.M.; BALSA, A.; TABOADA, V.M.; SANMARTÍ, R.; MARENCO, J.L.; SARABIA, F.N.; GÓMEZREINO, J.; ÁLVARO-GRACIA, J.M.; IVORRA, J.A.R.; LOJO, L.; PLASENCIA, C.; CARMONA, L. El uso de abatacept en artritis reumatoide: revisión de la evidencia y recomendaciones. Reumatol. Clín., 2012. (in press). Available at: < http://www.elsevier.es/sites/default/files/elsevier/eop/ S1699-258X(12)00134-9.pdf >. Accessed on: 23 nov. 2012.

MORELAND, L.W.; ALTEN, R.; VAN DEN BOSCH, F.; APPELBOOM, T.; LEON, M.; EMERY, P.; COHEN, S.; LUGGEN, M.; SHERGY, W.; NUAMAH, I.; BECKER, J.C. Costimulatory blockade in patients with rheumatoid arthritis: a pilot, dose-finding, double-blind, placebocontrolled clinical trial evaluating CTLA-4Ig and LEA29Y eighty-five days after the first infusion. Arthritis Rheum., v.46, n.6, p.1470-1479, 2002.

RUBBERT-ROTH, A.; FINCKH, A. Treatment options in patients with rheumatoid arthritis failing initial TNF inhibitor therapy: a critical review. Arthritis Res. Ther., v.11 suppl 1, p.S1, 2009.

RUSSELL, A.; BERESNIAK, A.; BESSETTE, L.; HARAOUI, B.; RAHMAN, P.; THORNE, C.; MACLEAN, R.; DUPONT, D. Cost-effectiveness modeling of abatacept versus other biologic agents in DMARDS and anti-TNF inadequate responders for the management of moderate to severe rheumatoid arthritis. Clinical Rheumatol., v.28, n.4, p.403-412, 2009.

RUSSELL, A.; BERESNIAK, A.; BESSETTE, L.; HARAOUI, B.; RAHMAN, P.; THORNE, C.; MACLEAN, R.; DUPONT, D. Cost-effectiveness modeling of abatacept versus other biologic agents in DMARDS and anti-TNF inadequate responders for the management of moderate to severe rheumatoid arthritis. Clinical Rheumatol., v.28, n.4, p.403-412, 2009. 
SALLIOT, C.; FINCKH, A.; KATCHAMART, W.; LU, Y.; SUN, Y.; BOMBARDIER, C.; KEYSTONE, E. Indirect comparisons of the efficacy of biological antirheumatic agents in rheumatoid arthritis in patients with an inadequate response to conventional disease-modifying antirheumatic drugs or to an anti-tumour necrosis factor agent: a metaanalysis. Ann. Rheum. Dis., v.70, n.2, p.266-271, 2011.

SCHIFF, M.; KEISERMAN, M.; CODDING, C.; SONGCHAROEN, S.; BERMAN, A.; NAYIAGER, S.; SALDATE, C.; LI, T.; ARANDA, R.; BECKER, J.C.; LIN, C.; CORNET, P.L.; DOUGADOS, M. Efficacy and safety of abatacept or infliximab vs placebo in ATTEST: a phase III, multi-centre, randomised, double-blind, placebocontrolled study in patients with rheumatoid arthritis and an inadequate response to methotrexate. Ann. Rheum. Dis., v.67, n.8, p.1096-1103, 2008.

SINGH, J.A.; CHRISTENSEN, R.; WELLS, G.A.; SUAREZALMAZOR, M.E.; BUCHBINDER, R.; LOPEZ-OLIVO, M.A.; GHOGOMU, E.T.; TUGWELL, P. A network meta-analysis of randomized controlled trials of biologics for rheumatoid arthritis: a Cochrane overview. Can. Med. Assoc. J., v.181, n.11, p.787-796, 2009.

SMOLEN, J.S.; ALETAHA, D.; KOELLER, M.; WEISMAN, M.H.; EMERY, P. New therapies for treatment of rheumatoid arthritis. Lancet, v.370, n.9602, p.1861-1874, 2007.

TANG, B.; RAHMAN, M.; WATERS, H.C.; CALLEGARI, P. Treatment persistence with adalimumab, etanercept, or infliximab in combination with methotrexate and the effects on health care costs in patients with rheumatoid arthritis. Clin. Ther., v. 30, n. 7, p. 1375-1384, 2008.

TOUSSIROT, E.; WENDLING, D. The use of TNF-alpha blocking agents in rheumatoid arthritis: an overview. Expert Opin. Pharmacother., v.5, n.3, p.581-594, 2004.
WEINBLATT, M.; COMBE, B.; COVUCCI, A.; ARANDA, R.; BECKER, J.C.; KEYSTONE, E. Safety of the selective costimulation modulator abatacept in rheumatoid arthritis patients receiving background biologic and nonbiologic disease-modifying antirheumatic drugs: A one-year randomized, placebo-controlled study. Arthritis Rheum., v.54, n.9, p.2807-2816, 2006.

WEINBLATT, M.; SCHIFF, M.; GOLDMAN, A.; KREMER, J.; LUGGEN, M.; LI, T.; CHEN, D.; BECKER, J.C. Selective costimulation modulation using abatacept in patients with active rheumatoid arthritis while receiving etanercept: a randomised clinical trial. Ann. Rheum. Dis., v.66, n.2, p.228-234, 2007.

WESTHOVENS, R.; ROBLES, M.; XIMENES, A.C.; NAYIAGER, S.; WOLLENHAUPT, J.; DUREZ, P.; GOMEZ-REINO, J.; GRASSI, W.; HARAOUI, B.; SHERGY, W.; PARK, S.H.; GENANT, H.; PETERFY, C.; BECKER, J.C.; COVUCCI, A.; HELFRICK, R.; BATHON, J. Clinical efficacy and safety of abatacept in methotrexate-naive patients with early rheumatoid arthritis and poor prognostic factors. Ann. Rheum. Dis., v.68, n.12, p.1870-1877, 2009a.

WESTHOVENS, R.; KREMER, J.M.; MORELAND, L.W.; EMERY, P.; RUSSELL, A.S.; LI, T.; ARANDA, R.; BECKER, J.C.; QI, K.; DOUGADOS, M. Safety and efficacy of the selective costimulation modulator abatacept in patients with rheumatoid arthritis receiving background methotrexate: a 5-year extended phase IIB study. $J$. Rheumatol., v.36, n.4, p.736-742, 2009b.

ZHANG, J.; YU, K.F. What's the relative risk? A method of correcting the odds ratio in cohort studies of common outcomes. Jama, v.280, n.19, p.1690-1691, 1998.

Received for publication on $22^{\text {nd }}$ March 2012 Accepted for publication on $25^{\text {th }}$ October 2012 